\title{
22. COARSE FRACTION OF PLIO-PLEISTOCENE SEDIMENTS FROM DEEP SEA DRILLING PROJECT HOLE 552A, NORTHEAST ATLANTIC ${ }^{1}$
}

\author{
Andrew C. Morton, British Geological Survey, Keyworth ${ }^{2}$
}

\begin{abstract}
The acid insoluble coarse fractions of the glacial-interglacial sequence of Hole 552A in the NE Atlantic are made up of varying amounts of terrigenous detritus, biogenic silica, and pyroclastic material, principally volcanic glass. Volcanic ash content varies significantly over the entire interval, and the three North Atlantic ash horizons of Ruddiman and Glover (1972) can be recognized satisfactorily. The terrigenous detritus is of mixed metamorphic-basaltic type and probably originated on the Greenland landmass.
\end{abstract}

\section{INTRODUCTION}

The Plio-Pleistocene of Hole 552A is the most complete record to date of high latitude Northern Hemisphere glaciation. There were two principal objectives behind the undertaking of a coarse-fraction study on this material. The first was to establish the nature of the terrigenous fraction, with the intention of determining the possible sediment source. The second was to provide correlation points by means of volcanic ash abundance and, in particular, to locate the three ash levels noted by Ruddiman and Glover (1972) and Sigurdsson and Loebner (1981), which were dated, respectively, as 9,400 years ago, 64,700 years ago, and 340,000 years ago.

\section{METHODS}

Following carbonate determinations on whole-rock and coarse-fraction samples by $0.6 \mathrm{~N}$ acetic-acid treatment (Zimmerman et al., this volume) the remaining, acid-insoluble, 74 to $125 \mu \mathrm{m}$ fractions of selected samples were examined petrographically. This took three forms. Relatively widely spaced samples from Cores 1 through 10 were examined in detail for major compositional variations. The volcanic glass abundances in Cores 1 and 2 were determined on a more closely spaced sample set. Finally, a small number of samples were analyzed for heavy mineral content, following separation from the light minerals by gravity-settling in bromoform of s.g. 2.80. The results of these analyses are shown in Tables 1 to 3 . The chemistry of the volcanic glass was investigated by electron microprobe analysis, using an energy-dispersive X-ray analyzer. Results of this are shown in Table 4.

\section{DISCUSSION}

The individual constitutents of the samples group naturally into three-terrigenous, biogenic, and pyroclastic. The terrigenous component includes quartz, feldspar, mica, rock fragments, opaques (in part), and virtually all the heavy minerals; the biogenic group comprises spicules, diatoms, and radiolarians; and the pyroclastic component is largely made up of volcanic glass, with some opaques and very minor amounts of heavy minerals and plagioclase.

\footnotetext{
${ }^{1}$ Roberts, D. G., Schnitker, D., et al., Init. Repts. DSDP, 81: Washington' (U.S. Govt. Printing Office).

Present address: British Geological Survey, Keyworth, Nottingham NG12 5GG, United Kingdom.
}

\section{Detrital Components}

The terrigenous fraction is of arkosic composition (quartz:feldspar:lithic grains average 62:32:6), the preponderance of polycrystalline and strained monocrystalline quartz suggesting a source largely of metamorphic basement. Rock fragments also indicate a metamorphic component, with phyllite and schist fragments common, but basalt and chert occur frequently, particularly the former, indicating some contribution from exposed lavas. Some radiating masses of quartz crystals, occurring as rounded grains, are possibly vesicle infills from the same source.

\section{Heavy Minerals}

Heavy mineral results also suggest a mixed metamorphic-basaltic terrain (Table 3). The major heavy minerals are augite, epidote, and hornblende, with garnet and hypersthene also significant. Both augite and hornblende and augite and epidote show strong negative correlations ( $r=-0.90$ and -0.72 , respectively), suggesting that the augite had a different provenance. On the other hand epidote and hornblende were probably derived from similar source rocks, since they show a moderate positive correlation $(r=+0.47)$. The epidote-hornblende group indicates derivation from metamorphic basement: the augite indicates a basaltic terrain. Although some augite is undoubtedly of pyroclastic origin (Sample 552A-5-3, $135 \mathrm{~cm}$ ), there is no correlation between the pyroclast content and the amount of augite in the whole-rock fraction (as determined by combining the data in Tables 1 and 3) $(r=0.01)$, indicating that by far the most important input of augite was by detrital means.

Both the whole-rock fraction and the heavy mineral fraction therefore indicate a mixed metamorphic-basaltic source, with their respective contributions varying through time, presumably dependent on the changing movement of land ice. Greenland satisfies these criteria, possessing both extensive tracts of metamorphic basement and large areas of exposed basalt (both in East and West Greenland). The presence of the rare heavy 
Table 1. Constitution of acid-insoluble $74 \mu \mathrm{m}-125 \mu \mathrm{m}$ fractions of selected samples from Hole 552A.

\begin{tabular}{|c|c|c|c|c|c|c|c|c|c|c|c|c|c|c|c|c|}
\hline $\begin{array}{l}\text { Sub- } \\
\text { bottom } \\
\text { depth } \\
\text { (m) }\end{array}$ & $\begin{array}{l}\text { Core-Section } \\
\text { (level in } \mathrm{cm} \text { ) }\end{array}$ & $\begin{array}{c}\text { Total } \\
\text { carbon- } \\
\text { ate }^{\mathrm{a}}\end{array}$ & $\begin{array}{c}\text { Coarse } \\
\text { fraction }\end{array}$ & $\begin{array}{l}\text { Carbonate } \\
\text { in coarse } \\
\text { fraction }\end{array}$ & Quartz & $\begin{array}{l}\text { Potash } \\
\text { feldspar }\end{array}$ & $\begin{array}{l}\text { Plagio- } \\
\text { clase } \\
\text { feldspar }\end{array}$ & Mica & $\begin{array}{l}\text { Rock } \\
\text { frag- } \\
\text { ments }\end{array}$ & $\begin{array}{l}\text { Sponge } \\
\text { spicules }\end{array}$ & $\begin{array}{l}\text { Diatoms } \\
\text { and } \\
\text { radio- } \\
\text { larians }\end{array}$ & $\begin{array}{l}\text { Volcanic } \\
\text { glass }\end{array}$ & $\begin{array}{l}\text { Glauco- } \\
\text { nite }\end{array}$ & Opaques & $\begin{array}{l}\text { Heavy } \\
\text { min- } \\
\text { erals }\end{array}$ & $\begin{array}{c}\text { Heavy } \\
\text { mineral } \\
\text { analysis? }\end{array}$ \\
\hline 0.69 & $1-1,68$ & 20 & 16 & 62 & 39 & 15 & 3 & 1 & 5 & & & 20 & 2 & 12 & 3 & - \\
\hline 1.90 & $1-2,39$ & 82 & 43 & 87 & 45 & 22 & 8 & 4 & 6 & 6 & & 1 & & 5 & 3 & - \\
\hline 2.60 & $1-2,109$ & 42 & 18 & 91 & 54 & 23 & 4 & 1 & 4 & tr & & 6 & 1 & 2 & 5 & + \\
\hline 3.20 & $1-3,19$ & 50 & 41 & 77 & 45 & 20 & 6 & 5 & 3 & 2 & & 13 & 1 & 1 & 4 & + \\
\hline 6.32 & $2-2,81$ & 91 & 16 & 98 & 33 & 9 & 5 & I & 3 & 14 & 26 & 3 & & 5 & 1 & - \\
\hline 7.20 & $2-3,19$ & 12 & 12 & 29 & 33 & 23 & 3 & 5 & 3 & & & 26 & 1 & 2 & 4 & + \\
\hline 10.88 & $3-2,37$ & 25 & 14 & 66 & 61 & 22 & 5 & 2 & 4 & & & 1 & 2 & 2 & 1 & + \\
\hline 12.50 & $3-3,49$ & 83 & 54 & 96 & 59 & 28 & 4 & 1 & 1 & 1 & & & tr & 1 & 5 & - \\
\hline 13.15 & $3-3,119$ & 4 & 6 & 17 & 68 & 23 & 2 & tr & 3 & & & & 2 & tr & 2 & + \\
\hline 14.52 & $4-1,51$ & 14 & 6 & 38 & 50 & 25 & 4 & tr & 12 & & & 1 & 1 & 2 & 5 & + \\
\hline 15.12 & $4-1,111$ & 80 & 33 & 88 & 50 & 22 & 3 & 3 & 6 & 4 & & 9 & 1 & 2 & tr & - \\
\hline 16.01 & $4-2,50$ & 21 & 16 & 48 & 67 & 20 & 4 & 2 & 5 & & & & i & $\mathrm{tr}$ & 1 & + \\
\hline 17.71 & $4-3,70$ & 10 & 20 & 17 & 54 & 19 & 2 & 5 & 8 & & & 1 & 1 & 2 & 8 & + \\
\hline 18.13 & $4-3,112$ & 18 & 10 & 45 & 58 & 26 & 2 & 2 & 6 & & & & tr & 1 & 5 & + \\
\hline 19.72 & $5-1,71$ & 33 & 25 & 77 & 56 & 25 & 3 & 3 & 8 & & & & tr & 1 & 4 & + \\
\hline 20.12 & $5-1,111$ & 83 & 44 & 91 & 63 & 26 & 2 & tr & 5 & $\mathrm{tr}$ & & & 1 & 2 & 1 & + \\
\hline 20.92 & $5-2,41$ & 9 & 43 & 86 & 53 & 22 & 7 & 3 & 4 & 1 & & 1 & 4 & 1 & 4 & + \\
\hline 22.69 & $5-3,68$ & 16 & 10 & 37 & 47 & 24 & 5 & 2 & 11 & 1 & & tr & I & $\mathrm{tr}$ & 9 & + \\
\hline 23.36 & $5-3,135$ & & Not analyze & & & 3 & 1 & & & & & 86 & & 9 & 1 & + \\
\hline 23.71 & $5-4,20$ & 19 & 6 & 9 & 62 & 21 & 3 & tr & 5 & & & 5 & 3 & & 1 & + \\
\hline 30.61 & $7-2,10$ & 30 & 17 & 47 & 45 & 32 & 3 & 1 & 5 & & & 4 & 1 & 1 & 8 & + \\
\hline 31.54 & $7-2,103$ & 33 & 21 & 74 & 61 & 26 & 1 & i & 6 & & & 2 & & & 3 & - \\
\hline 31.82 & $7-2,131$ & 87 & 40 & 96 & 38 & 26 & 9 & 3 & 5 & 8 & & 6 & $\mathrm{tr}$ & 1 & 4 & - \\
\hline 32.38 & $7-3,37$ & 46 & 17 & 0 & 63 & 19 & 6 & 1 & 6 & $=$ & & 2 & 2 & $\mathrm{tr}$ & 1 & + \\
\hline 34.09 & $8-1,8$ & 18 & 4 & 7 & 60 & 20 & 6 & i & 6 & 1 & & 1 & tr & 1 & 4 & + \\
\hline 35.92 & $8-2,41$ & 88 & 33 & 98 & 33 & 22 & 4 & tr & 4 & 25 & 2 & 3 & 3 & 1 & 3 & - \\
\hline 37.09 & $8-3,8$ & 53 & 14 & 67 & 48 & 23 & 4 & 1 & 6 & 1 & & 8 & & 4 & 5 & + \\
\hline 40.90 & $9-2,39$ & 35 & 20 & 46 & 52 & 28 & 1 & $i$ & 8 & & & 7 & & 1 & 2 & + \\
\hline 41.35 & $9-2,84$ & 24 & 14 & 40 & 49 & 17 & 4 & 2 & 5 & 1 & tr & 13 & & 3 & 6 & + \\
\hline 42.14 & $9-3,13$ & 44 & 26 & 73 & 57 & 28 & 3 & tr & 3 & 1 & & 4 & 1 & tr & 3 & + \\
\hline 43.07 & $9-3,106$ & 96 & 26 & 100 & 29 & 11 & 1 & & 5 & 12 & 37 & 1 & & 2 & 2 & - \\
\hline
\end{tabular}

a Data from Zimmerman et al., this volume.

Table 2. Variation in volcanic glass abundance in Cores 1 and 2, Hole $552 \mathrm{~A}$.

\begin{tabular}{|c|c|c|c|c|c|c|}
\hline $\begin{array}{l}\text { Core-Section } \\
\text { (level in } \mathrm{cm} \text { ) }\end{array}$ & $\begin{array}{c}\text { Sub- } \\
\text { bottom } \\
\text { depth } \\
\text { (m) }\end{array}$ & $\begin{array}{l}\text { Volcanic } \\
\text { glass in } \\
\text { insoluble } \\
\text { residue } \\
(\%)\end{array}$ & $\begin{array}{c}\text { Insoluble } \\
\text { residue } \\
\text { in coarse } \\
\text { fraction }^{a} \\
(\%)\end{array}$ & & $\begin{array}{c}\text { Coarse } \\
\text { fraction } \\
\text { of whole } \\
\text { rock }^{\mathrm{a}} \\
(\%)\end{array}$ & $\begin{array}{c}\text { Volcanic } \\
\text { glass in } \\
\text { whole } \\
\text { rock } \\
(\%)\end{array}$ \\
\hline $1-1,20$ & 0.21 & 3.5 & 16 & & 51 & 0.29 \\
\hline $1-1,38$ & 0.39 & 12.5 & 31 & & 23 & 0.89 \\
\hline $1-1,68$ & 0.69 & 20.0 & 38 & & 16 & 1.02 \\
\hline $1-1,109$ & 1.10 & 4.0 & 26 & s & 34 & 0.35 \\
\hline $1-2,10$ & 1.62 & 2.5 & 18 & & 35 & 0.16 \\
\hline $1-2,39$ & 1.90 & 1.0 & 13 & & 43 & 0.06 \\
\hline $1-2,79$ & 2.30 & 1.0 & 21 & & 25 & 0.05 \\
\hline $1-2,109$ & 2.60 & 6.0 & 9 & & 18 & 0.10 \\
\hline $1-3,19$ & 3.20 & 13.0 & 23 & s & 41 & 1.23 \\
\hline $1-3,49$ & 3.50 & 2.0 & 16 & & 34 & 0.11 \\
\hline $1-3,69$ & 3.70 & 7.0 & 20 & & 25 & 0.35 \\
\hline $1, \mathrm{CC}(10)$ & 4.05 & 4.5 & 35 & & 21 & 0.33 \\
\hline $2-1,40$ & 4.41 & 3.0 & 24 & & 25 & 0.18 \\
\hline $2-1,81$ & 4.81 & 4.0 & 14 & & 32 & 0.18 \\
\hline $2-1,110$ & 5.11 & 3.0 & 12 & & 31 & 0.13 \\
\hline $2-2,1$ & 5.52 & 2.5 & 7 & & 44 & 0.08 \\
\hline $2-2,49$ & 6.00 & 7.5 & 14 & & 26 & 0.27 \\
\hline $2-2,81$ & 6.32 & 3.0 & 2 & & 16 & 0.01 \\
\hline $2-2,110$ & 6.61 & 4.5 & 10 & & 15 & 0.07 \\
\hline $2-2,130$ & 6.81 & 1.0 & 20 & & 15 & 0.03 \\
\hline $2-3,19$ & 7.20 & 26.0 & 71 & & 12 & 2.22 \\
\hline $2-3,50$ & 7.51 & 0.0 & 40 & & 15 & 0.00 \\
\hline $2-3,100$ & 8.01 & 1.0 & 31 & & 20 & 0.06 \\
\hline $2-3,139$ & 8.40 & 0.0 & 36 & & 10 & 0.00 \\
\hline
\end{tabular}

a Data from Zimmerman et al., this volume. mineral species piedmontite is a further indication of a Greenland source (Morton, this volume).

\section{Biogenic Silica}

There is a reasonably good positive correlation between biogenic silica and total carbonate $(r=+0.63)$, indicating that its productivity matches that of the calcareous microfossils. Biogenic silica only becomes abundant where carbonate exceeds $90 \%$. This is close to the threshold value for appearance of the more delicate biosiliceous organisms such as the diatoms and radiolarians, whereas spicules occur commonly in sediments with carbonate content down to $80 \%$. This suggests that the sponges may be more tolerant of climatic conditions.

\section{Pyroclastic Input}

The pyroclastic input to the sediment is fairly sporadic with no apparent pattern to its distribution, although there appears to have been a relative lull in volcanic activity in the middle of the early Pleistocene (Core 3 to Core 5, Section 2). There is a suspicion of higher pyroclastic content in the glacial periods than in the interglacials, since samples with particularly high pyroclast content $(>15 \%)$ never contain more than $50 \%$ carbonate, but in general there is a poor correlation between pyroclast and carbonate content $(r=-0.11)$. Most of the pyroclastic material is glassy; both clear and brown types occur in variable proportions, varying between slightly and highly vesiculated. Some opaque grains are clearly of pyroclastic origin (Sample $552 \mathrm{~A}-5-3,135 \mathrm{~cm}$ ), and are probably tachylyte. Minor components include augite and plagioclase.

The constituents of the volcanic ash are virtually identical to those of Site 404 (Harrison et al., 1979) and also 
Table 3. Heavy mineral content of selected samples from Hole 552A (74-125 $\mu \mathrm{m}$ fraction).

\begin{tabular}{|c|c|c|c|c|c|c|c|c|c|c|c|c|c|c|c|c|c|c|c|c|c|c|}
\hline $\begin{array}{l}\text { Sub- } \\
\text { bottom } \\
\text { depth } \\
\text { (m) }\end{array}$ & $\begin{array}{l}\text { Core-Section } \\
\text { (level in cm) }\end{array}$ & $\begin{array}{l}\text { Aegirine- } \\
\text { augite }\end{array}$ & $\begin{array}{l}\text { Anda- } \\
\text { lusite }\end{array}$ & Apatite & Augite & $\begin{array}{l}\text { Chlor- } \\
\text { itoid }\end{array}$ & $\begin{array}{l}\text { Clino- } \\
\text { zoisite }\end{array}$ & Epidote & Garnet & $\begin{array}{l}\text { Horn- } \\
\text { blende }\end{array}$ & $\begin{array}{l}\text { Hyper- } \\
\text { sthene }\end{array}$ & Kyanite & $\begin{array}{c}\text { Pied- } \\
\text { montite }\end{array}$ & Rutile & $\begin{array}{c}\text { Silli- } \\
\text { manite }\end{array}$ & Sphene & $\begin{array}{l}\text { Stau- } \\
\text { rolite }\end{array}$ & Topaz & $\begin{array}{c}\text { Tour- } \\
\text { maline }\end{array}$ & $\begin{array}{c}\text { Tre- } \\
\text { molite }\end{array}$ & Zircon & $\begin{array}{c}\text { Total } \\
\text { grains } \\
\text { counted }\end{array}$ \\
\hline 1.90 & $1-2,109$ & 0.5 & & . & 67.0 & & & 6.5 & 2.5 & 18.0 & 2.0 & & & 0.5 & 0.5 & 1.0 & & & & & 1.5 & 200 \\
\hline 3.20 & $1-3,19$ & & & & 56.0 & & & 8.0 & 2.0 & 23.5 & 2.0 & 2.0 & & 4.5 & & 1.0 & & & & & 1.0 & 90 \\
\hline 7.20 & $2-3,19$ & 1.0 & & & 68.0 & & & 7.0 & 4.0 & 17.0 & 0.5 & 0.5 & & & 0.5 & 1.0 & & & & & 0.5 & 200 \\
\hline 10.88 & $3-2,37$ & & 0.5 & 0.5 & 40.0 & & & 15.0 & 8.0 & 26.0 & 1.0 & 0.5 & & 1.0 & 0.5 & 3.0 & 0.5 & & 1.5 & & 2.0 & 200 \\
\hline 13.15 & $3-3,119$ & & & 1.0 & 21.5 & & & 21.5 & 14.0 & 35.0 & & 1.0 & & 3.0 & 1.0 & 1.0 & 1.0 & & & & & 80 \\
\hline 14.52 & $4-1,51$ & & & & 77.0 & & & 8.5 & 2.0 & 8.5 & 0.5 & 0.5 & & & & 1.5 & & & & & 1.5 & 151 \\
\hline 16.01 & $4-2,50$ & & $\mathbf{R}$ & & 28.5 & & 0.5 & 19.5 & 5.0 & 38.0 & 2.0 & 1.0 & $\mathrm{R}$ & 0.5 & 0.5 & 2.5 & 1.0 & & 0.5 & 0.5 & R & 200 \\
\hline 17.71 & $4-3,70$ & & 0.5 & & 36.0 & & 0.5 & 6.5 & 11.5 & 32.5 & 6.0 & 1.0 & $\mathrm{R}$ & 1.0 & 1.0 & 2.0 & 1.0 & & 0.5 & & $R$ & 200 \\
\hline 18.13 & $4-3,112$ & & 0.5 & & 35.0 & $\mathbf{R}$ & & 13.5 & 9.0 & 34.0 & 2.5 & 0.5 & & & 1.0 & 2.5 & & & 0.5 & 0.5 & 0.5 & 200 \\
\hline 19.72 & $5-1,71$ & & 0.5 & & 40.5 & & & 10.5 & 12.0 & 26.5 & 5.0 & 0.5 & & & & 2.0 & 1.5 & & & R & 1.0 & 200 \\
\hline 20.92 & $5-2,41$ & & & & 42.0 & & & 13.5 & 6.0 & 31.5 & 3.5 & 0.5 & & & 0.5 & 2.0 & & & & & 0.5 & 141 \\
\hline 22.69 & $5-3,68$ & & & 0.5 & 61.5 & & 0.5 & 8.5 & 6.0 & 16.5 & 2.5 & 0.5 & & 1.5 & & 1.5 & & & & & 0.5 & 200 \\
\hline 23.36 & $5-3,135$ & & & 2.0 & 98.0 & & & & & $\mathrm{R}$ & & & & & & & & & & & & 200 \\
\hline 23.71 & $5-4,20$. & 1.0 & & 3.0 & 41.5 & & & 6.5 & 4.0 & 36.5 & 4.5 & & & & & & & & 2.0 & & 1.0 & 106 \\
\hline 30.61 & $7-2,10$ & & & & 56.5 & & 0.5 & 5.0 & 4.5 & 28.0 & 2.5 & 1.0 & $\mathrm{R}$ & & & 1.0 & 0.5 & & 0.5 & & & 200 \\
\hline 32.38 & $7-3,37$ & & & 0.5 & 48.0 & & & 9.0 & 5.5 & 28.5 & 1.5 & 0.5 & & & 0.5 & 2.5 & & 0.5 & 2.0 & & 1.0 & 200 \\
\hline 34.09 & $8-1,8$ & & & & 17.5 & & & 14.5 & 11.5 & 41.5 & 8.0 & & & & & 2.0 & & & 1.0 & 1.0 & 3.0 & 103 \\
\hline 37.09 & $8-3,8$ & & & 0.5 & 42.0 & & & 10.5 & 5.0 & 31.0 & 9.0 & & & $\mathrm{R}$ & & 1.0 & & & $R$ & & 1.0 & 200 \\
\hline 40.90 & $9-2,39$ & & & & 38.5 & & & 16.5 & 9.0 & 23.5 & 4.0 & & & 0.5 & & 2.0 & 3.0 & & 1.0 & & 2.0 & 200 \\
\hline 41.35 & $9-2,84$ & & & & 51.5 & & 0.5 & 8.0 & 7.0 & 23.0 & 3.5 & 0.5 & & 0.5 & & 3.0 & 1.0 & & 1.0 & & 0.5 & 200 \\
\hline 42.14 & $9-3,13$ & & & & 35.0 & R & 1.0 & 13.5 & 9.0 & 30.0 & 7.0 & 1.0 & & & & 1.0 & & & & 0.5 & 1.0 & 200 \\
\hline
\end{tabular}

Note: $\mathrm{R}$ denotes presence in abundances less than $0.5 \%$. 
Table 4. Volcanic glass compositions from Sample 552A-5-3, $135 \mathrm{~cm}$ as determined by electron microprobe.

\begin{tabular}{ccc}
\hline $\begin{array}{c}\text { Oxide } \\
(\%)\end{array}$ & $\begin{array}{c}\text { Pale brown } \\
\text { glass }\end{array}$ & $\begin{array}{c}\text { Colorless } \\
\text { glass }\end{array}$ \\
\hline $\mathrm{Si}$ & 53.6 & 69.1 \\
$\mathrm{Al}$ & 13.1 & 12.3 \\
$\mathrm{Ti}$ & 1.6 & 0.4 \\
$\mathrm{Cr}$ & 0.1 & 0.0 \\
$\mathrm{Fe}^{\mathrm{a}}$ & 11.7 & 2.7 \\
$\mathrm{Mg}$ & 1.9 & 0.0 \\
$\mathrm{Mn}$ & 0.4 & 0.0 \\
$\mathrm{Ca}$ & 4.8 & 0.7 \\
$\mathrm{Na}$ & 1.4 & 1.6 \\
$\mathrm{~K}$ & 2.4 & 4.7 \\
$\mathrm{P}$ & 0.5 & 0.0 \\
$\mathrm{~S}$ & 0.2 & 0.1 \\
Total & 91.7 & 91.6 \\
\hline
\end{tabular}

${ }^{a}$ All Fe calculated as $\mathrm{FeO}$.

to ashes of Plio-Pleistocene age of Site 346 on the Icelandic Plateau (Sylvester, 1976). The glass is distinctly bimodal in composition (Table 2), with the $\mathrm{SiO}_{2}$ content of the brown glass between 50 and $55 \%$ and that of the colorless glass between 65 and $70 \%$. These values closely accord with those determined by Harrison et al. (1979) by refractive index methods for the Site 404 ash. Electron microprobe analysis indicates that the glass has been extensively hydrated, as shown by the low total of the analysis (Table 2).

It is generally accepted that the volcanic ash of PlioPleistocene age in the North Atlantic and NorwegianGreenland Sea originated from eruptions on Iceland (Ruddiman and Glover, 1972; Sylvester, 1976; Harrison et al., 1979; Donn and Ninkovich, 1980; Sigurdsson and Loebner, 1981). The explosive nature of the volcanism is ascribed to the interaction of the magma with water, particularly, in this case, with glacial meltwater, in the manner described by Heiken (1975).

The more detailed investigation of the volcanic ash abundance of Cores 1 and 2 has revealed three levels at which volcanic glass is particularly abundant (Table 2, Fig. 1). These are of particular importance in that they equate with the three levels reported by Ruddiman and Glover (1972). The first maximum lies between Samples $552 \mathrm{~A}-1-1,38 \mathrm{~cm}$ and $1-1,68 \mathrm{~cm}$, with an extrapolated peak at Sample 552A-1-1, $50 \mathrm{~cm}$. This level was therefore deposited some 9,400 years ago. The second occurs at Sample 552A-1-3, $19 \mathrm{~cm}$, equivalent to the 64,700 yearago level, and the third is at Sample 552A-2-3, $19 \mathrm{~cm}$, deposited some 340,000 years ago.

\section{CONCLUSIONS}

The bulk of the terrigenous, ice-rafted material in the Plio-Pleistocene of Hole 552A was transported south or southeast from Greenland. Two distinct source areas contributed in varying proportions, one contributing metamorphic basement material, the other basaltic detritus. Biogenic silica plays a relatively unimportant role except in the most calcareous levels, where radiolarians and

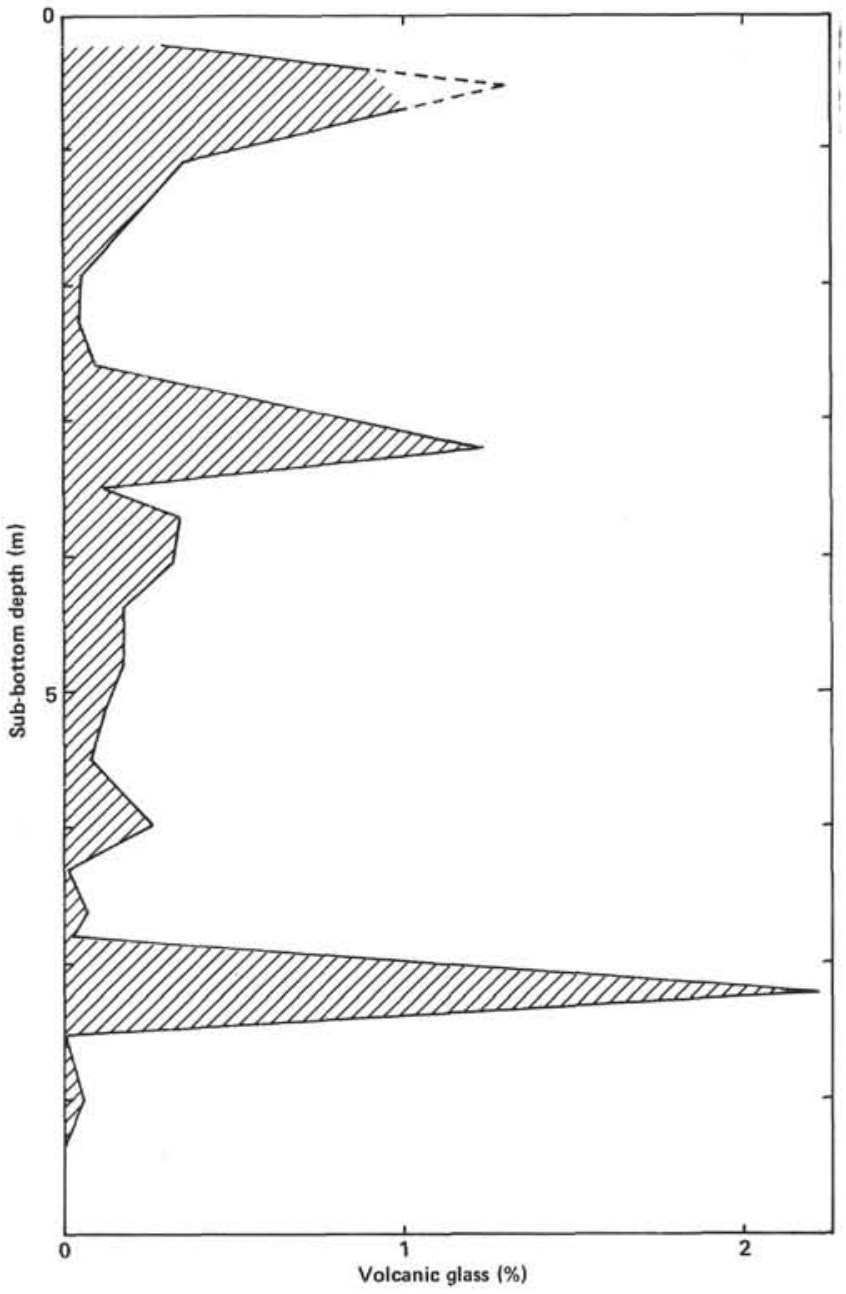

Figure 1. Variation in abundance of volcanic glass in Cores 1 and 2 of Hole 552A, showing the presence of three levels of high ash abundance.

diatoms also flourish. Pyroclastic input is variable, being a consistent but relatively low-key influence in the lower part of the sequence (Cores 5 to 9), virtually disappearing in Cores 3 and 4, and consistently present in Cores 1 and 2. Only one undisturbed ash layer is present $(5-3,86 \mathrm{~cm})$ and correlates with the one found at Hole $404(2-6,80 \mathrm{~cm})$. The three levels of high ash abundance in Cores 1 and 2 correspond to the ash levels of Ruddiman and Glover (1972) and are therefore dated as 9,400 years ago, 64,700 years ago, and 340,000 years ago.

\section{ACKNOWLEDGMENTS}

The author is grateful to the U.K. Department of Energy for funding shipboard and shore-based research. This paper is published with the approval of the Director of the British Geological Survey (N.E.R.C.).

\section{REFERENCES}

Donn, W. L., and Ninkovich, D., 1980. Rate of Cenozoic explosive volcanism in the North Atlantic Ocean inferred from deep sea cores. J. Geophys. Res., 85:5455-5460.

Harrison, R. K., Knox, R. W. O'B., and Morton, A. C., 1979. Petrography and mineralogy of volcanogenic sediments from DSDP Leg 48, southwest Rockall Plateau, Sites 403 and 404. In Montadert, 
L., Roberts, D. G., et al., Init. Repts. DSDP, 48: Washington (U.S. Govt. Printing Office), 771-785.

Heiken, G., 1975. An atlas of volcanic ash. Smithsonian Contrib. Earth Sci., 12:1-101.

Ruddiman, W. F., and Glover, L. K., 1972. Vertical mixing of ice-rafted volcanic ash in North Atlantic sediments. Geol. Soc. Am. Bull., 83:2817-2836.

Sigurdsson, H., and Loebner, B., 1981. Deep-sea record of Cenozoic explosive volcanism in the North Atlantic. In Self, S., and Sparks,
R. S. J. (Eds.), Tephra Studies: London (D. Riedel Publishing Co.), pp. 289-316.

Sylvester, A. G., 1976. Petrography of volcanic ashes in deep-sea cores near Jan-Mayen Island: Sites 338, 345-350 DSDP Leg 38. Init. Repts. DSDP, Suppl. to Vols. 38, 39, 40, and 41: Washington (U.S. Govt. Printing Office), 101-106.

Date of Acceptance: August 29, 1983 